\title{
BIMBINGAN TEKNIS INVENTARISASI DAN IDENTIFIKASI TUMBUHAN BAGI SDN 045 TARAKAN MELALUI PEMBUATAN HERBARIUM BERBASIS POTENSI LOKAL EKOSISTEM HUTAN TROPIS
}

\section{Technical Guidance of Plant Inventory and Indentification for SDN 045 Tarakan Through Making Herbarium Based on Local Potencies of Tropical Forest Ecosystem}

\author{
Fadhlan Muchlas Abrori $^{{ }^{*}}$, Aidil Adhani ${ }^{1}$, Darius Rupa ${ }^{1}$ \\ ${ }^{1}$ Jurusan Pendidikan Biologi, Fakultas Keguruan dan Ilmu Penddidikan, Universitas Borneo Tarakan, \\ Jl. Amal Lama no. 1 Tarakan \\ * Penulis Korespodensi : fadhlan1991@gmail.com
}

\begin{abstract}
ABSTRAK
Tarakan merupakan salah satu kota di Kalimantan Utara yang memiliki kekayaan biodiversitas, terutama keragaman tumbuhan di hutan tropis. Berbanding terbalik dengan luasnya hutan dan banyaknya sumber daya, pembelajaran di Sekolah Dasar di Kota Tarakan sangat kurang kontekstual dalam memperkenalkan kekayaan hutan kepada siswa. SDN 045 Tarakan sebagai sekolah mitra berlokasi di sekitar hutan tropis, akan tetapi pembelajarannya sangat jarang memanfaatkan potensi hutan tropis. Penanggulangan permasalahan kurang kontekstualnya pembelajaran di Sekolah Dasar adalah dengan memberikan bimbingan teknik pengembangan media berbasis potensi lokal dalam bentuk herbarium. Metode pelaksanaan kegiatan ini terdiri dari 5 tahapan, yaitu: observasi, persiapan, penyusunan panduan, pelaksanaan, dan evaluasi. Hasil kegiatan ini didapatkan bahwa pada tes identifikasi tumbuhan pada guru terdapat kenaikan nilai dari rata-rata nilai 35 (pre-test) dan 85.4 (pos-test). Penilaian psikomotorik (keterampilan) pembuatan herbarium guru didapat nilai yang baik, dengan rata-rata nilai tiap aspek $>80$. Penilaian produk herbarium juga didapatkan nilai yang sangat baik dengan rata-rata nilai tiap aspek $>80$.
\end{abstract}

Kata Kunci: Herbarium, Potensi Lokal, Hutan Tropis, Bimbingan Teknis

\begin{abstract}
Tarakan is one of the cities in North Kalimantan that has a lots of biodiversity, especially the diversity of tropical plants. Contrary, learning activity in Elementary Schools in Tarakan is not contextual in presenting tropical forest biodiversity to students. SDN 045 Tarakan as a partner school located is close to tropical forests, but its learning activity rarely utilizes the potential biodiversity of tropical forests. Problem solving of the problem is through technical guidance. The implementation of technical guidance consists of 5 stages, namely: observation, preparation, developing guide book, implementation, and evaluation. The result of this activity about teachers skill to identifying plant the average mean score is 35 (pre-test) and 85.4 (post-test). Psychomotor skill of teacher about herbarium making obtained good grades, with an average mean $>80$. The herbarium product assessment also obtained excellent grades with an average mean $>80$.
\end{abstract}

Keywords: Herbarium, Local Potencies, Tropical Forest, Technical Guidance

\section{PENDAHULUAN}

Tarakan merupakan salah satu kota di Kalimantan Utara yang memiliki kekayaan biodiversitas, terutama keragaman tumbuhan di hutan tropis. Posisi Tarakan sebagai daerah tropis memiliki hutan yang sangat luas. Luas hutan di daerah Tarakan berdasarkan SK Menhut No. 79 Tahun
2001 tentang Penunjukan Kawasan Hutan dan Perairan Provinsi Kalimantan Timur, Kawasan hutan di kota Tarakan seluas 4.900 Ha. Berdasarkan SK Menhut No. 143/Kpts-II/2003 pembagian hutan di kota Tarakan yaitu: 2.400 Ha hutan lindung dan 2.400 Ha hutan produksi. Pada tahun 2006 
sebagai salah satu langkah peningkatan daya dukung kawasan hutan dalam Rencana Tata Ruang dan Wilayah Kota Tarakan Berdasarkan Perda No. 3 Tahun 2006, luas hutan di Kota Tarakan bertambah menjadi $6.600 \mathrm{Ha}$ lebih. Penambahan luas hutan di Kota Tarakan dengan rincian penambahan luas dari hutan kota berdasarkan Perda No. 21 Tahun 1999, yaitu: 766,6 Ha hutan mangrove berdasarkan Perda No.4 tahun 2002, 157 Ha hutan wisata INHUTANI dan 420 Ha Hutan Adat (KPHL Kota Tarakan, 2014).

Luasnya hutan di Tarakan merupakan salah satu sumber daya potensial yang bisa dimanfaatkan oleh berbagai jenis aktifitas, salah satunya adalah pengenalan potensi lokal dalam bidang pendidikan khususnya bagi siswa Sekolah Dasar. Berbanding terbalik dengan luasnya hutan dan banyaknya sumber daya, pembelajaran di Sekolah Dasar di Kota Tarakan sangat kurang kontekstual dalam memperkenalkan kekayaan hutan kepada siswa. Abrori dan Adhani (2017) menyatakan kurang kontekstualnya pembelajaran di Sekolah Dasar akan berdampak kepada minimnya pengetahuan siswa dalam mengenal sumber daya di lingkungan sekitarnya.

Penanggulangan permasalahan kurang kontekstualnya pembelajaran di Sekolah Dasar adalah dengan memberikan bimbingan teknik kepada guru di kelas sebagai fasilitator dalam proses pembelajaran untuk membudayakan pendekatan kontekstual dalam setiap pembelajaran. Sugiyanto (2012) menyatakan pendekatan kontekstual mampu membantu siswa untuk mengembangkan kemampuan dalam mengaitkan materi pelajaran dengan kehidupan sehari-hari. Depdiknas dalam Supinah (2008) juga menyatakan bahwa pendekatan pembelajaran yang dikembangkan dengan tujuan agar pembelajaran berjalan dengan produktif dan bermakna bagi siswa adalah pembelajaran kontekstual.

Pembelajaran kontekstual di dalam kelas dapat terwujud dengan pemanfaatan media yang mendukung. Salah satu media yang mendukung dalam pembelajaran kontekstual adalah media realia dalam bentuk herbarium. Herbarium dapat diartikan sebagai kumpulan kering yang secara sistematis diberi nama dan digunakan dalam proses pembelajaran (Tucker dan Calabrese. 2005). Lavoie (2013) juga menyatakan bahwa melalui pemanfaatan herbarium dalam pembelajaran mampu memberikan gambaran kepada siswa mengetahui potensi lokal tumbuhan daerah tersebut ditinjau dari sudut pandang biogeografi dan lingkungan.

SDN 045 Tarakan berdasarkan lokasinya terletak di sekitar hutan tropis, akan tetapi walaupun potensi lokal hutan tropis disekitar sekolah melimpah guru-guru kurang memanfaat potensi lokal yang ada dan lebih menekankan kepada pembelajaran tekstual saja dengan menggunakan buku teks dan lembar kerja. Berdasarkan latar belakang dan permasalahan kurang kontekstualnya pembelajaran di SDN 045 Tarakan, maka dirancang bimbingan teknis inventarisasi dan identifikasi tumbuhan bagi guru SDN 045 Tarakan melalui pembuatan herbarium berbasis potensi lokal ekositem hutan tropis. Hasil dari bimbingan teknis ini akan membantu guru dalam pengelolaan potensi lokal menjadi media objek nyata dalam bentuk herbarium, sehingga bisa dijadikan sebagai media bantu dalam pembelajaran di kelas.

\section{METODE}

\section{Metode Pendekatan Kegiatan}

Metode pendekatan dalam kegiatan ini terbagi 2 cara yaitu penjabaran pemahaman dan pengaplikasian, yang dirinci sebagai berikut:

1. Penyampaian konsep pendekatan kontekstual, serta cara/teknik penerapannya pada pembelajaran di dalam kelas

2. Pengaplikasian melalui bimbingan teknis inventarisasi dan identifikasi, melalui cara pengenalan, pengidentifikasian dan pembuatan herbarium 
Metode Pelaksanaan Kegiatan

Metode Pelaksanaan kegiatan bimbingan teknis berdasarkan pada
(Halaman 67-74)

beberapa langkah kegiatan yang dijabarkan berdasarkan alur pada Gambar 1.

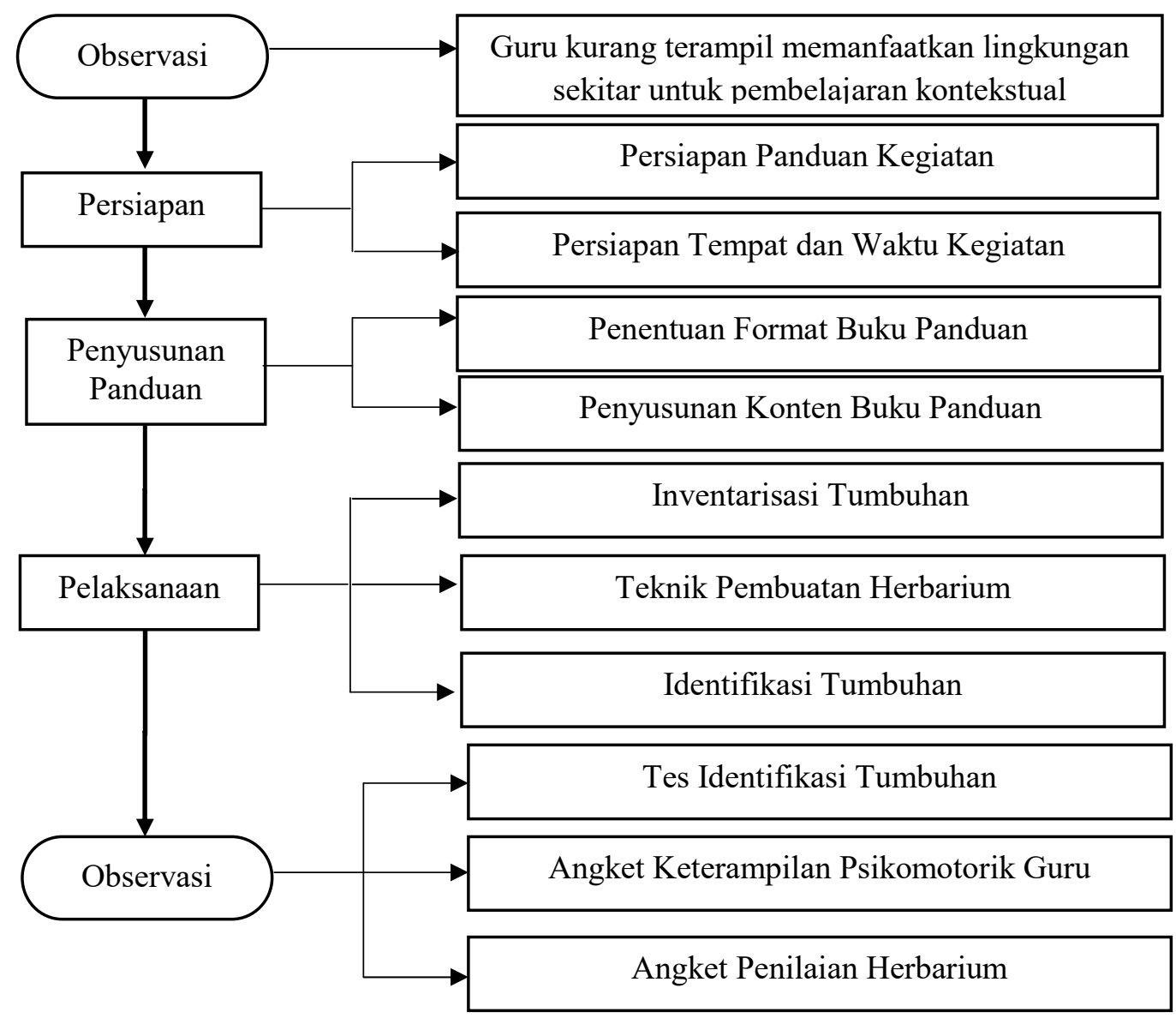

Gambar 1. Alur Pelaksanaan Kegiatan

Berdasarkan alur di atas, maka tahapan kegiatan dijabarkan sebagai berikut:

1. Observasi Awal

Observasi awal dilakukan untuk mendapatkan permasalahan mendasar pada sekolah mitra di SDN 045 Tarakan. Berdasarkan hasil observasi awal didapatkan data bahwa guru jarang menerapkan pembelajaran kontekstual didalam kelas, karena guru kurang terampil dalam mengembangkan media berbasis potensi lokal.

2. Persiapan Pelaksanaan Kegiatan

Pada tahapan persiapan pelaksanaan terdapat 2 hal yang dibahas, yaitu: persiapan konten isi dalam panduan pelaksanaan kegiatan bimbingan teknis dan persiapan waktu dan tempat. Pada persiapan konten dan isi panduan, secara garis besar terdiri dari: pengenalan herbarium dan teknik pembuatan herbarium. Berdasarkan diskusi pada tahapan pelaksanaan kegiatan akan dilaksanakan di SDN 045 Tarakan pada tanggal $10-30$ November 2017.

3. Penyusunan Panduan Pembuatan Herbarium

Panduan pembuatan herbarium disusun berdasarkan konten-konten yang telah disepakati pada tahapan persiapan. Konten dalam buku panduan yaitu:

a. Pengenalan herbarium, terkait definisi, fungsi dan jenis-jenis herbarium 
b. Pengoleksian spesimen herbarium, terkait perlengkapan (alat dan bahan) pembuatan herbarium, dan persyaratan pengkoleksian spesimen untuk herbarium

c. Pencatatan data, dan Pengeringan spesimen

d. Penempelan, pelabelan dan perawatan

Penyusunan buku panduan

berdasarkan pada beberapa sumber terkait pembuatan herbarium, diantaranya: Victor et al., (2004); Tucker dan Calabrese (2005); Greening Australia (2012);

4. Pelaksanaan Bimbingan Teknis

Tahap bimbingan teknis guru akan dilatih untuk proses inventarisasi tumbuhan terutama tumbuhan di ekosistem hutan tropis, serta tahapan pembuatan herbariumnya. Pada tahap ini guru juga diajarkan bagaimana proses pengidentifikasian tumbuhan, proses pengidentifikasi tumbuhan mengacu kepada beberapa buku identifikasi, diantaranya: Soepadmo et al., (2002); Stenis (2008); Tjitrosoepomo (2009); Sudarmono (2010).

5. Evaluasi Pelaksanaan Program

Pada kegiatan ini secara garis besar terdapat 3 evaluasi pelaksanaan program, yaitu:

a. Tes pengidentifikasian tumbuhan

b. Angket keterampilan psikomotorik guru

c. Angket Penilaian herbarium

\section{HASIL DAN PEMBAHASAN Observasi Awal}

Observasi awal merupakan tahapan awal dalam pelaksanaan bimbingan teknis. Observasi ditujukan untuk mengetahui permasalahan mendasar pada guru-guru di SDN 045 Tarakan. Pada observasi awal terdapat 3 hal pokok yang ditanyakan kepada guru di SDN 045 Tarakan, yaitu:

1. Pengetahuan terkait herbarium
2. Jenis media pembelajaran yang pernah dikembangkan guru

3. Pemanfaatan potensi lokal dalam pengembangan media pembelajaran.

Pengetahuan guru terkait herbarium digambarkan pada Gambar 2, untuk mengetahuai pengetahuan guru terkait herbarium dilakukan wawancara kepada 19 orang guru di SDN 045 Tarakan.

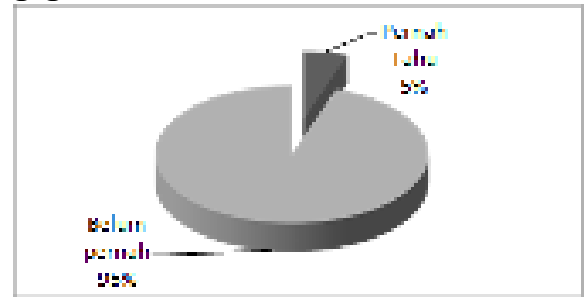

Gambar 2. Pengetahuan Awal Guru terkait Herbarium berdasarkan Hasil Wawancara

Berdasarkan grafik tersebut hanya 1 orang (6\%) yang mengetahui tentang herbarium, sementara sebanyak 18 orang sisanya (94\%) tidak mengetahui tentang herbarium.

Pada observasi awal juga ditanyakan terkait jenis-jenis media pembelajaran yang pernah diterapkan oleh guru (Gambar 3). Berdasarkan hasil wawancara didapatkan hasil bahwa hanya sekitar 7 guru yang pernah mengembangkan media, sementara sisanya belum pernah mengembangkan media. Media yang dikembangkan hanya sebatas modul sebanyak 5 orang $(27 \%)$, poster sebanyak 1 orang $(5 \%)$, video sebanyak 1 orang (5\%), dan 12 orang $(63 \%)$ sisanya belum pernah mengembangkan media pembelajaran.

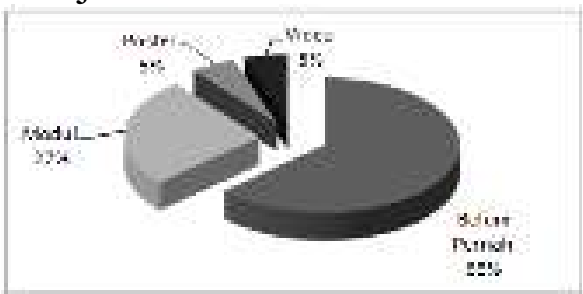

Gambar 3. Jenis media yang pernah dikembangkan oleh guru

Hal lain yang ditanyakan kepada guru pada observasi awal, adalah pemanfaatan 
media pembelajaran berbasis potensi lokal oleh guru (Gambar 4). Berdasarkan hasil wawancara hanya 1 orang guru $(5 \%)$ yang pernah memanfaatkan potensi lokal sebagai media pembelajaran, sementara 18 orang lainnya (95\%) belum pernah melakukan.

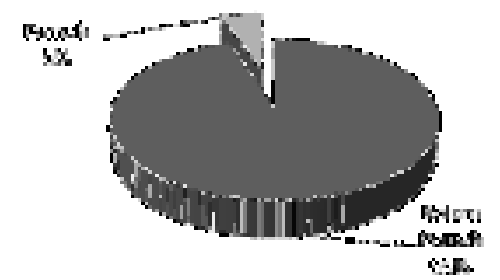

Gambar 4. Pemanfaatan Potensi Lokal dalam Pengembangan Media oleh Guru

\section{Persiapan Pelaksanaan Kegiatan}

Berdasarkan hasil observasi, disusun rencana persiapan pelaksanaan kegiatan, yang terdiri dari penyusunan konten yang akan diajarkan dalam bimbingan teknis, penentuan waktu dan tempat kegiatan. Konten dalam bimbingan teknis berdasarkan hasil diskusi meliputi hal-hal berikut: pengenalan herbarium, alat dan bahan dalam pembuatan herbarium, cara pembuatan dan praktik pembuatan herbarium. Bimbingan teknis dilaksanakan 10-30 November 2017 di SDN 045 Tarakan.

\section{Penyusunan Panduan Pembuatan Herbarium}

Berdasarkan hasil masukan pada tahapan persiapan kegiatan, dilakukan penyusunan buku panduan pembuatan herbarium dengan konten yang telah didiskusikan oleh guru. Konten pada buku panduan pembuatan herbarium terdiri dari beberapa konten berikut:

1. Pengenalan herbarium, terkait definisi, fungsi dan jenis-jenis herbarium

2. Pengoleksian spesimen herbarium, terkait perlengkapan (alat dan bahan) pembuatan herbarium, dan persyaratan pengkoleksian spesimen untuk herbarium

3. Pencatatan data, dan pengeringan spesimen
4. Penempelan, pelabelan dan perawatan

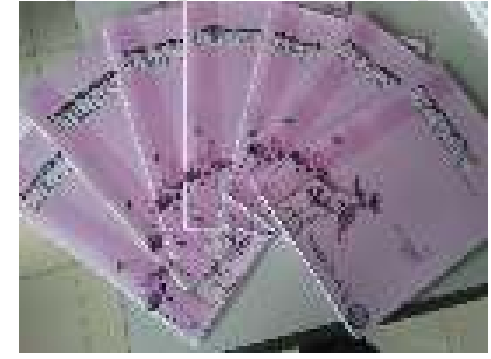

Gambar 5. Buku Panduan Pembuatan Herbarium

\section{Pelaksanaan Bimbingan Teknis}

Secara garis besar, pelaksanaan bimbingan teknis dibagi menjadi 2 kegiatan besar, yaitu:

1. Penjelasan umum terkait herbarium (definisi herbarium, herbarium sebagai media pembelajaran, pemilihan spesimen, pengeringan spesimen, pelabelan herbarium dan perawatan.

2. Pembuatan herbarium berdasarkan hasil penjelasan umum terkait herbarium.

Pelaksanaan bimbingan teknis dimulai dengan pengenalan herbarium kepada guru, dan cara pemanfaatannya dalam proses pembelajaran. Tahapan selanjutnya dijelaskan terkait syarat spesimen yang dapat dijadikan herbarium (sekaligus dijelaskan alat dan bahan yang digunakan dalam pengumpulan spesimen). Tahapan selanjutnya, dijelaskan cara penempelan spesimen kering (mounting), pemberian label (posisi label yang sesuai) dan perawatan herbarium.

Tahapan selanjutnya adalah tahap pembuatan herbarium, pembuatan herbarium dibagi dalam beberapa kegiatan selama 3 tahapan kegiatan selama 3 hari, yang dirinci sebagai berikut:

1. Hari 1 : pengumpulan spesimen, pembuatan herbarium (pencatatan data, press spesimen dan pengeringan).

2. Hari 2 : penempelan herbarium (mounting), pada penempelan herbarium guru dibagi menjadi 2 kelompok, yaitu: kelompok dengan mounting melalui jahitan, dan 
kelompok dengan mounting melalui pengeleman

3. Hari 3 : penyimpanan, dan perawatan herbarium.

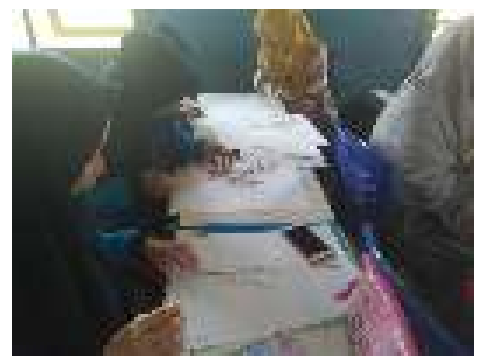

Gambar 6. Proses Pembuatan Herbarium

Tahapan terakhir pada kegiatan ini adalah pengenalan beberapa nama tumbuhan khususnya yang berada di daerah Tarakan kepada guru-guru. Guruguru diajarkan bagaimana membedakan tanaman berdasarkan morfologi bunganya sehingga nantinya guru lebih mudah dalam mencari nama spesies tumbuhan tersebut.

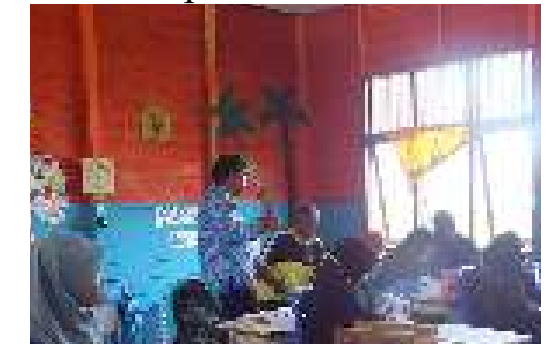

Gambar 7. Tahapan Pengidentifikasian Tumbuhan

Kegiatan akhir dalam bimbingan teknis ini adalah evaluasi kegiatan yang dibagi menjadi:

a. Tes pengidentifikasian tumbuhan, merupakan tes singkat untuk mengetahui pemahaman guru terkait jenis-jenis tumbuhan di Tarakan

b. Angket keterampilan psikomotorik guru, merupakan penilaian guru dalam pembuatan herbarium

c. Angket Penilaian herbarium, penilaian produk akhir herbarium

Tes pengidentifikasian tumbuhan diberikan pada sebelum pelaksanaan bimbingan teknis dan setelah pelaksanaan bimbingan teknis. Hasil dari tes identifikasi digambarkan pada Gambar 8.

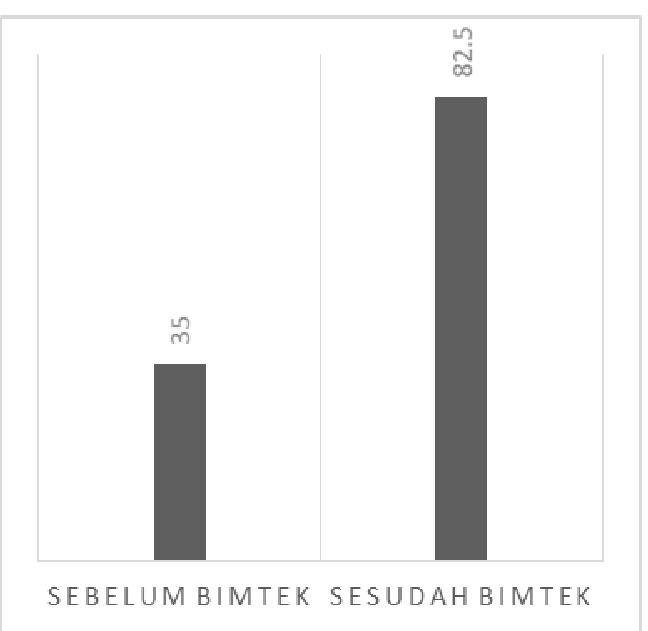

Gambar 8. Hasil tes Identifikasi Tumbuhan

Berdasarkan gambar 8 hasil tes identifikasi sebelum pelaksanaan bimbingan teknis adalah 35 dan setelah pelaksanaan adalah 82.5. Peningkatan pada setelah bimbingan teknis cukup tinggi, karena pada sebelumnya guru belum pernah mengetahui jenis tumbuhan di lingkungan sekitar. Setelah dilakukan bimbingan teknis, guru memiliki gambaran jenis-jenis tumbuhan yang bisa ditemukan di lingkungan sekitar.

Angket psikomotorik guru diukur berdasarkan keterampilan guru dalam pembuatan herbarium yang disajikan pada Tabel 1.

Tabel 1. Rata-Rata Penilaian Keterampilan Pembuatan Herbarium Guru

\begin{tabular}{|c|c|c|}
\hline No & Aspek & $\begin{array}{c}\text { Rata-Rata } \\
\text { Nilai }\end{array}$ \\
\hline \multicolumn{3}{|c|}{ Persiapan } \\
\hline 1. & $\begin{array}{l}\text { Kelengkapan bahan dalam } \\
\text { pengeringan, penempelan, dan } \\
\text { perawatan }\end{array}$ & 80 \\
\hline 2. & $\begin{array}{l}\text { Kelengkapan alat dalam } \\
\text { pengeringan, penempelan, dan } \\
\text { perawatan }\end{array}$ & 83,5 \\
\hline \multicolumn{3}{|c|}{ Kegiatan Praktikum } \\
\hline 1. & $\begin{array}{l}\text { Penggunaan Alat dan Bahan } \\
\text { dalam pembuatan herbarium }\end{array}$ & 85 \\
\hline 2. & $\begin{array}{l}\text { Fokus perhatian dalam pembuatan } \\
\text { herbarium }\end{array}$ & 81 \\
\hline 3. & $\begin{array}{l}\text { Terlibat aktif bersama kelompok } \\
\text { dalam pembuatan herbarium }\end{array}$ & 87,5 \\
\hline 4. & $\begin{array}{l}\text { Melaksanakan pembuatan } \\
\text { herbarium sesuai dengan prosedur }\end{array}$ & 85 \\
\hline 5. & $\begin{array}{l}\text { Menyajikan hasil herbarium di } \\
\text { depan kelas secara sistematis dan } \\
\text { komunikatif }\end{array}$ & 83 \\
\hline 6. & Membuatan kesimpulan sesuai & 81 \\
\hline
\end{tabular}


(e-ISSN: 2579-9797)

Diterima: Mei 2018

Dipublikasikan: Juni 2018

$$
\text { hasil }
$$

Kegiatan Akhir

1. Merapikan Alat

2. Merapikan bahan

Berdasarkan hasil penilaian keterampilan pembuatan herbarium guru dalam pembuatan didapatkan data yang sangat baik dengan rata-rata nilai untuk keseluruhan aspek diatas 80. Guru memiliki ketertarikan yang tinggi dalam pelaksanaan kegiatan karena pembuatan media herbarium tidak pernah dilakukan oleh guru sebelumnya.

Setelah dilakukan penilian terhadap psikomotorik guru terkait herbarium, kemudian dilakukan penilaian produk herbarium yang disajikan pada Tabel 2 .

Tabel 2 Penilaian Herbarium

\begin{tabular}{|c|c|c|}
\hline No & Aspek & $\begin{array}{c}\text { Rata-Rata } \\
\text { Nilai }\end{array}$ \\
\hline \multicolumn{3}{|c|}{ Kelengkapan Herbarium } \\
\hline 1. & $\begin{array}{l}\text { Organ spesimen tumbuhan } \\
\text { untuk herbarium memenuhi } \\
\text { syarat }\end{array}$ & 100 \\
\hline 2. & $\begin{array}{l}\text { Bagian dalam herbarium } \\
\text { lengkap }\end{array}$ & 100 \\
\hline \multicolumn{3}{|c|}{ Kemenarikan Herbarium } \\
\hline 1. & $\begin{array}{l}\text { Kemenarikan tampilan } \\
\text { herbarium }\end{array}$ & 85 \\
\hline 2. & $\begin{array}{l}\text { Penataan letak dalam } \\
\text { herbarium }\end{array}$ & 85 \\
\hline 3. & $\begin{array}{l}\text { Warna spesimen dalam } \\
\text { herbarium }\end{array}$ & 80 \\
\hline \multicolumn{3}{|c|}{ Hasil Akhir } \\
\hline & Herbarium tidak berjamur & 80 \\
\hline & Tingkat kekeringan & 80 \\
\hline
\end{tabular}

Penilaian akhir herbarium sangat baik dengan rata-rata nilai diatas 80 . Nilai tertinggi pada kelengkapan spesimen dan bagian dalam herbarium. Kelengkapan organ spesimen yang dikumpulkan oleh guru-guru di SDN 045 Tarakan memenuhi persyaratan minimal herbarium. Victor et al., (2004) dan Abrori et al., (2016) menyatakan persyaratan minimal dalam pembuatan herbarium, yaitu: 1) untuk tumbuhan besar atau pohon dan semak, dikoleksi sebagian cabangnya dengan panjang $30-40 \mathrm{~cm}$ yang mempunyai organ lengkap: daun (minimal punya 3 daun), 
Flora yang dapat diterapkan dalam

\section{DAFTAR RUJUKAN}

Abrori, F.M., Yulida, R., Adhani, A., Wijarini, F., dan Nugroho, E.D. (2016). Media Pembelajaran Biologi. Yogyakarta : Genom

Abrori dan Adhani (2017). Pengembangan Buku Ajar Berbasis Potensi Lokal Keragaman Tumbuhan Paku di Daerah Tarakan. Seminar Salingdidik 4 : 328-332

Greening Australia (2012) Collect, Prepare, and Preserve Plant Specimens. Australia : Aboriginal Landcare Education Program. Australian Government

Lavoide, C. (2013). Biological collections in an ever changing world: Herbaria as tools for biogeographical and environmental studies. Perspectives in Plant Ecology, Evolution and Systematics 15: $68-76$

Tucker, A.O. dan Calabrese, L. (2005). The Use and Methods of Making a Herbarium/Plant Specimens : An Herb Society of America Guide. Kirtland : The Herb Society of America

Soepadmo, E., Latif, A., Kiew, R., Lee, H.S., Saw, L.G., dan Chung, R.C.K. (2002). Tree Flora of Sabah And Sarawak Volume Four. Forest Research Institute Malaysia, Sabah pembelajaran di kelas.

Forestry Department Malaysia and

Sarawak Forestry Department

Malaysia

Stenis, C.G.G.V. (2008). Flora. Jakarta : PT. Pradnya Paramita.

Sudarmono. (2010). Ensiklopedia Flora. Jakarta : PT. Kharisma Ilmu.

Sugiyanto (2012). Penerapan Pendekatan Kontekstual untuk Meningkatkan Aktivitas Belajar Matematika Sekolah Dasar Negeri 01 Pontianak Utara. Artikel Publikasi. Universitas Tanjungpura Pontianak.

Supinah. 2008. Pembelajaran Matematika SD dengan Pendekatan Kontekstual dalam Melaksanakan KTSP. Yogyakarta : Depdiknas

Tjitrosoepomo, G. (2009). Taksonomi Tumbuhan Schizophyta, Thallophyta, Bryophyta dan Pteridophyta. Yogyakarta : Gadjah Mada University Press.

Tjitrosoepomo, G. (2009) Taksonomi Tumbuhan Spermatophyta. Yogyakarta : Gadjah Mada University Press.

Victor, E.J., Koekemor, M. dan Fish, L. 2004) Herbarium Essentials. South Africa : The Project Coordinator Southern African Botanical Diversity Network. 